\title{
MUITAS PESSOAS, MUITAS VOZES
}

Valdemar Valente Junior*

A começar pela prestigiosa apresentação de Ronaldo Correia de Brito, afirma-se em As primeiras pessoas, coletânea de contos de Cesar Cardoso, a opção deliberada das narrativas em ocuparem o lugar sugerido pelo título. Torna-se imperativo observar cada conto com o olhar do distanciamento, supondo-se que foram escritos por mãos que não tomam parte na composição desse conjunto. O narrador apresenta-se como figura indispensável, ao assumir a voz do discurso, notabilizando uma ação que dinamiza cada conto, na medida em que a distância imposta o libera de interferir sobre a matéria narrada. Ao lado disso, a rapidez com que as cenas se desenrolam, indistintamente, concorre para que $A$ *valdemarvalente@gmail.com

Doutor em Ciência da Literatura pela UFRJ. Participa do Programa de Pos-Doutorado da UERJ. Professor Assistente da Universidade Castelo Branco e Professor Adjunto da UniverCidade.

primeiras pessoas expresse o sentido funcional das histórias narradas por quem as efetivamente vivem, lhes dando a inegável condição do que lhes é verossímil.

O passado recente é narrado com requinte de detalhes, envolvendo o futebol, o samba e as noitadas, agora restritas ao intervalo de um melancólico café da manhã onde a inóspita realidade contradiz o tempo que passou. Ainda efetiva-se a carga de erotismo perverso da tia, servindo-se da imaginação, na criação da lenda do "choro-chororô" para seduzir o sobrinho. Uma narrativa parece surgir de dentro de outra, servindo-se do espaço exíguo do conto para construir sua condição fabular. Também o vômito noturno acompanha 
a protagonista numa narrativa que tende a pôr em destaque o destino sem retorno de cada personagem. Estes são quase todos incompletos e expressam a ânsia de completude que os faz ainda mais parciais e precários. Por isso, todas as primeiras pessoas situam-se como exemplo nítido de atores em busca de um papel que se adeque ao desconforto cotidiano.

A narrativa de Cesar Cardoso caminha na direção de um encontro que não ocorre, na busca pela porta de saída, em fuga desembestada do sofrimento e da dor. No entanto, ao buscar uma saída para o impasse da conquista amorosa sob o risco de perda, uma dessas primeiras pessoas resolve roubar poemas de Arnaldo Antunes, escrevendo-lhe uma carta em que pede ajuda, uma vez que sua mulher descobre a fraude e quer a separação. Daí o texto parecer não ter dono, pressupondo-se que o assalto à poesia consagrada possa ser um meio aceitável, o que se justifica na atitude em si mesma De todo modo, em certos contos, o narrador em primeira pessoa, que não possui nome próprio, expõe sua condição de gênero quando a narrativa já se encontra bastante encaminhada. Subitamente, ocorre uma revelação como "tive mais uma menina, além dos dois meninos que meu marido trouxe do primeiro casamento", ou ainda, "tenho até um orgulho desse lance porque eu sou assim também, dura na queda".

Por vezes, a questão geracional interfere diretamente, denunciando um determinado tempo vivido, a partir de referências específicas à Educação Moral e Cívica, Beatles, Mostra de Publicações Alternativas, Torquato Neto, Rolling Stones, "Alegria, alegria", bem como ao ambiente cultural da década de 1970, com direito à Casa do Estudante Universitário, no Flamengo, e à Faculdade de Letras, na Avenida Chile. Assim, "Bem unidos, façamos" traz à tona presenças como as de Paco Cac, Chacal e Adauto, poetas que ajudaram a compor parte deste cenário carioca, no clima de euforia e apreensão dos anos da ditadura militar. Por isso, a narrativa de Cesar Cardoso acena para a possibilidade do diálogo com o passado sem que isso consista numa nostalgia inócua. Os termos passados de algum modo coadunam-se à ação presente sugerindo situações atemporais.

Mais uma vez a distinção entre gêneros revela-se no final, quando em "Diz", o que supostamente seria um recado de amor de uma mulher, tendo como porta-voz o filho da pessoa amada, realiza-se por outro meio, quando o narrador pontua: "vai lá e diz só mais uma coisa pro teu pai, diz que eu estou muito cansado e que já não existe segredo entre nós”. Os contos de Primeiras pessoas colocam cada um dos narradores diante do prazer e da dor, de onde resulta a constatação da falibilidade do desejo do "humano vaga-lume" em apagar-se diante do insólito da vida para a qual foi condenado e da qual não há escapatória. Viver é o maior limite que se impõe à condição humana e a morte é um sonho de que não se acorda. 
A dependência afetiva, a solidão, a velhice, a necessidade de um recomeço, enfim, a condição do confinamento humano à grande cidade e aos relacionamentos que subitamente empobrecem vão perpassar a viagem de mudança para o mesmo lugar. $\mathrm{O}$ alimento das lembranças configura-se na repetição de procedimentos para os quais não há expectativa. O homem da cidade é alguém para quem as viagens são muito lentas, os deslocamentos reduzidos e as memórias para sempre. Deixar de lembrar uma pessoa pode representar o esquecimento de si mesmo. No fim, tudo esbarra no sentido das palavras de que todos são feitos. "Esquecer para lembrar" remeteria à trilogia de Carlos Drummond de Andrade, configurando-se na dor da memória a luta contra o esquecimento.

As primeiras pessoas pluraliza uma galeria de tipos sem nome cuja diferença apresenta-se como sinal da contingência de um mundo onde todos se inscrevem como representações. A resolução que cada conto sugere nem sempre corresponde ao desejo do que se supõe como a melhor saída, mas talvez, por esse motivo, denuncie o lugar incômodo que se tem que compartilhar num mundo desencantado. Por vezes, se salva o estado de euforia que transparece como um signo de esperança, numa espécie de saudosa utopia de uma geração que pensou em ser jovem para sempre. No entanto a sucessão de absurdos da vida contemporânea desmistifica o desejo legítimo de se ser feliz, em razão da violência, ratificando as situações de convívio problemático, das quais se torna improvável escapar ileso.

A dinâmica do presente não pode retroceder, por mais que os contos de Cesar Cardoso busquem flertar com o passado. A crise nas relações familiares, do ponto de vista da mulher, face à sucessão do tempo, torna-se visível no crescimento dos filhos, no aparecimento das rugas e no desinteresse do marido. "O cozimento dos suspiros" dialoga com versos de canções de Pixinguinha, Herivelto Martins e Caetano Veloso, denunciando o desejo do retorno a uma situação irreversível, quando a primeira pessoa arrepende-se de ter se esquivado à cantada do vizinho, acabando por romper com a monotonia cotidiana e reconsiderando o convite para assistir ao filme de Almodóvar. A solidão coletiva inunda de inquietação o diário de cada um dos personagens, expostos no bazar das coisas comuns, diante das quais não têm o devido valor.

Ao confessar-se a um jovem escritor, uma dessas primeiras pessoas comete o equívoco de atribuir a Jorge de Lima a autoria de $A$ idade do serrote, livro de memórias de Murilo Mendes. No entanto, o equívoco não invalida o desabafo do escritor ante o que considera um desrespeito a quem escreve no Brasil. Daí a falta do que dizer a quem espera receber conselhos, senão a certeza de que um escritor é alguém a quem 
se desaconselha pedir uma opinião. Por isso, o escritor resolve apoderar-se dos textos inéditos do jovem que lhe escreve, na medida em que aquilo que pensa em escrever já ter sido anteriormente escrito. Ao ler os escritos do postulante, efetiva-se uma inversão, querendo parecer que o lugar da literatura é não ter lugar, sendo que a invenção não é senão uma apropriação de todas as formas de textos que circulam.

O que parece constituir-se em regra geral acaba por contrariá-la, no conto "Pai é quem", quando a primeira pessoa tem seu nome revelado. Na verdade, Rodney tem o nome chamado por Agouro, que o surpreende cheirando cola no gramado da Candelária, quando o leva para o morro e o ensina a viver. Tratando-se de ensinar a viver, o fim das utopias apresenta-se em "Seres estranhos", com citações a Noel Rosa e Lupicínio Rodrigues, quando a primeira pessoa constata que tudo se esvaneceu. Engajados e desbundados de um tempo de sonhos estão agora diante de uma situação em que o capitalismo apoderou-se de todas as manifestações utópicas transformando-as em produtos de consumo. Assim reafirma-se a certeza de que o mundo mudou e o modelo socialista faliu, sendo que Cuba, numa paródia do poema de Drummond, é apenas um retrato na parede.

A descoberta do corpo e o amor entre duas meninas, na dimensão do que pode configurar-se num brinquedo, esbarra na incompreensão e na ideia de pecado da família evangélica.
O sentimento de culpa, os castigos corporais dos pais e a fala exaltada do pastor impõem um clima de medo e tirania à menina, que pensa ser o amor um "brinquedo" como brincar de bonecas. O mesmo amor denuncia a desilusão do motorista de táxi que monologa ao ouvido do passageiro em "Quarta à direita”. O sofrimento humano não tem fim, ou melhor, no fim encontra-se a revelação da dor no escuro do peito, como uma fotografia a que se rejeita retirar do álbum. Depois de décadas de união, a mulher do taxista é encontrada morta junto com seu amante entre escombros, no desabamento de um hotel barato.

As pequenas misérias do cotidiano constituem-se num componente atávico a que se incorporam sucessivos absurdos. A herança de fracassos confirma mais uma vez a situação dos personagens em fuga, para os quais resta a estação rodoviária, onde não há nada que preste. As máscaras desnudam-se de sua natural hipocrisia para expor nos contos de Cesar Cardoso a solidão de autômatos caminhando em direção ao nada, sem saber o rumo das situações externas, que não dependem de seus movimentos perdidos. A inutilidade das coisas assume uma frequência para a qual o vazio das ações confirma sua ausência de lugar. As pessoas espremem-se nas cidades entre encontrões e desencontros, espreitando umas às outras sem que $\mathrm{a}$ isso se dê uma razão. 
A classe média empobrecida, emparedada entre o morro e o asfalto, vivendo da lembrança do que não mais representa, oscila na posição a ser tomada diante dos ditames da violência. O tempo apresenta-se como matéria dando ênfase ao lugar que o presente ocupa na vida de quem parece não poder descolar-se da memória como espaço confortável, diante da falta de respostas às questões que se impõem. Assim, a memória ocupa espaços de importância decisiva em boa parte dos contos de As primeiras pessoas dando-lhes um sentido que funciona como eixo de ideias que procura esmiuçar no passado um sucedâneo às incertezas que o tempo acumula. A lembrança do acampamento com os colegas da faculdade de letras ou a imagens da irmã e do avô são marcas indeléveis do ritmo que Cesar Cardoso impõe a suas histórias.

O deslocamento inevitável dos personagens dá conta de um mundo que não mais existe, para quem vê suas intenções evadirem-se na curva do tempo. Em "A vida como ela não é”, contraria-se a ordem estabelecida, dando-se nome aos personagens, o que pouco acontece nos demais contos, além de situar a narrativa na terceira pessoa. No entanto, um narrador em primeira pessoa assume os rumos do texto, no último parágrafo, identificando cada um dos tipos que compõem o conto. Por fim, no conto que nomeia o volume impresso, o personagem reitera o lugar dos que perderam a vez deixando o tempo passar à revelia de seus atos. Ao revirar o amontoado de trastes acumulados, depara-se com a dolorosa ironia das lembranças num sonho com o poeta Manuel Bandeira. 